\title{
VÝSLEDKY MIKROPALEONTOLOGICKÉ REVIZE ŠARATICKÝCH CF VRTŮ
}

\author{
Results of micropalaeontological revision of Cf boreholes from Šaratice \\ Miroslav Bubík \\ Česká geologická služba, Leitnerova 22, 65869 Brno; e-mail: miroslav.bubik@geology.cz
}

(24-43 Šlapanice)

Key words: Carpathian Flysch Belt, Paleogene, biostratigraphy, Foraminifera

\begin{abstract}
Restudy of archive foraminifer slides from Šaratice boreholes and new field observations allowed revision of the geology in the margin of the Carpathian Flysch Belt southeast of Brno. In the marginal zone originally assigned to the Nermčice Formation newly three different formations were distinguished: Pouzdřany Formation of the Pouzdřany Nappe, and Němčice and Menilite formations of the Ždánice Nappe. Planktonic foraminifers were applied in biostratigraphical assignment of samples. Benthic communities were statistically evaluated using cluster analysis. Each formation has distinct microfossil taphocoenosis and characteristic benthic foraminifer community. Microfossil communities with abundant sponge spicules and diatom valves preserved in opal and also presence of small mollusc fauna and fish otoliths indicate that marginal zone of Ždánice Nappe was deposited little bit shallower than the more internal zones. Also lithology reflects different palaeoenvironment. Clays of the Menilite Formation are macroscopically undistinguishable from Hustopeče-type clays of the overlying Ždánice-Hustopeče Formation. The Ždánice-type sandstones are practically missing. Grey pelocarbonate concretions are frequent in both Menilite and Ždánice-Hustopeče formations. The marker lithologies of the Menilite Formation - the menilite chert and Dynów-type marlstone (or their analogues) - were not observed yet. Results of the revision show that the marginal zone of the Carpathian Flysch Belt in Saratice area comprises tectonic slices of mentioned formations, the number and order of whose change from borehole to borehole.
\end{abstract}

Úvod

Vnější okraj karpatského flyšového pásma jv. od Brna na styku s karpatskou předhlubní charakterizuje relativně špatná odkrytost geologického podloží. Pelitické horniny na okraji příkrovů tvoří plochý reliéf zakrytý aluviálními sedimenty Litavy a jejích prítoků a táhlé svahy zakryté koluviálními sedimenty. Geologická stavba této oblasti se stala předmětem strukturního výzkumu provedeného v 50. letech Moravskými naftovými doly (Cílek 1957). $\mathrm{V}$ rámci tohoto výzkumu byla vyhloubena řada Cf vrtů, které provrtaly okraj flyšového pásma a zpravidla dosáhly miocenních sedimentů karpatské předhlubně v podloží. V původním popisu vrtů Ša-10, Ša-12 a Ša-13 zařadil V. Cílek jíly a jílovce okraje flyšového pásma k němčickým vrstvám. Geologické výsledky vrtů posloužily v 80 . letech pro sestavení geologické mapy 24-431 Šlapanice v měřítku 1 : 25000 (Brzobohatý et al. 1987). Nové geologické mapování brněnské aglomerace přehodnocovalo v téže oblasti dostupné geologické podklady pro zjištění geologické stavby okraje flyšového pásma. Od doby vyhloubení vrtů v roce 1955 uplynulo mnoho let, během kterých došlo k výraznému zpřesnění biostratigrafie i litostratigrafie karpatského flyše. Výrazně pokročila taxonomie paleogenních planktonických foraminifer, což stabilizovalo biostratigrafickou zonaci (Olsson et al. 1999; Pearson et al. 2006). V litostratigrafii bylo vyřešeno detailní členění menilitového souvrství do 4 členů dobře korelovatelných naprríč tektonickými jednotkami. Tyto pokroky dávaly naději, že mikropaleontologická revize šlapanických Cf vrtů přinese detailnější členění okraje karpatského flyše v mapované oblasti.

\section{Materiál}

Východiskem revize byla mikrofauna z vrtů Ša-10, Ša-12, Ša-13 a Ša-15 (obr. 1) a textový popis vrtů (Cílek 1957). Mikrofauna ve Frankeho komůrkách (celkem 35 vzorků) je součástí mikropaleontologické hmotné dokumentace Moravských naftových dolů v Hodoníně. Součástí hmotné dokumentace jsou i další vzorky patřící k laaskému souvrství z podloží karpatských příkrovů, které nebyly bliže studovány. Separovaná mikrofauna obsahuje $\mathrm{v}$ mnoha případech pyritová jádra foraminifer, pyritové výplně chodbiček (Trichichnus? isp.) a pyritové hlízky. Pyrit ve větší či menší míře podlehl rozkladu za vzniku žlutých pseudomorfóz (jarosit?) a jehličkovitých krystalků sádrovce. Kyselina sírová, která se při rozkladu pyritu uvolňuje,

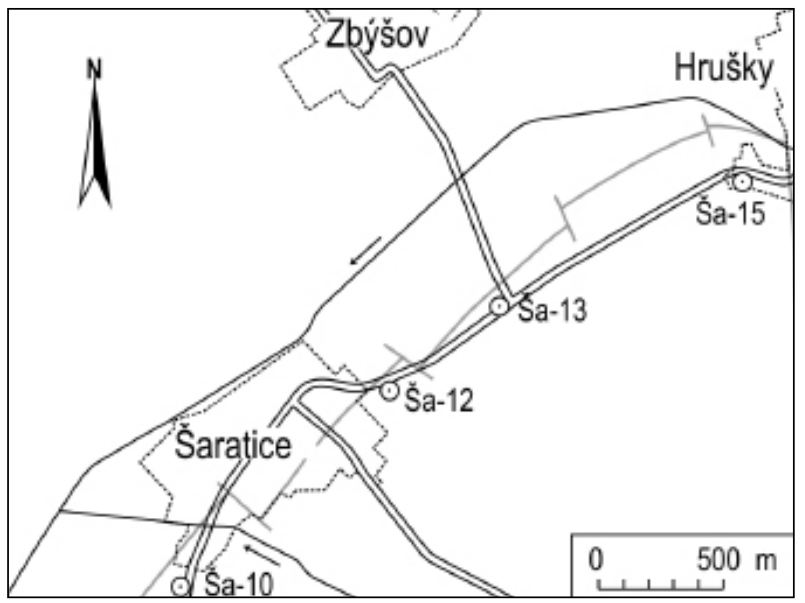

Obr. 1: Schematická mapka se situací šaratických Cf vrtů a vyznačenou linií nasunutí karpatských príkrovů.

Fig. 1: Schematic map with situation of Šaratice Cf boreholes and overthrust line of Carpathian nappes. 
znehodnotila mikrofaunu ve vzorcích s vysokým podílem pyritových objektů. V těchto vzorcích jsou původně vápnité schránky foraminifer přeměněny na bělavé sádrovcové (?) pseudomorfózy a morfologické detaily jsou ztraceny (např. textura stěny planktonu). Většina vzorků nicméně obsahuje dobře zachovalou, bohatou a diversifikovanou mikrofaunu bentických i planktonických foraminifer a dalších mikrofosilií (radiolarie, otolity, zuby a kosti ryb, dentikuly žraloků, drt’ mlžů, plžů a kelnatek, ostny ježovek, vzácně ostrakody a mechovky).

\section{Metodika}

K metodice vrtání Cf vrtů je důležité poznamenat, že šlo o vrtání s nepřímým výplachem (counterflush). Vzorky získané touto technologií mají obvykle charakter kusového jádra malého průměru. Dá se předpokládat, že mikrofauna byla získána plavením těchto jader. Nebylo zjištěno, zda se zachoval nějaký horninový materiál z těchto vrtů. Taxonomie a biostratigrafické zhodnocení planktonických foraminifer bylo provedeno podle atlasů planktonu Olsson et al. (1999) a Pearson et al. (2006). Geologická interpretace vzorků, neboli zařazení k litostratigrafické jednotce, byla provedena na základě datování podle planktonických foraminifer, složení tafocenóz (zejména bentických foraminifer) a litologie uvedené v popisu vrtu. K ověření geologické interpretace byla provedena shluková analýza tafocenóz pomocí softwarového balíčku statistických metod PAST 2.17 (viz Hammer et al. 2001). Pro statistické zpracování byla upravena distribuční tabulka mikrofauny (tab. 2). Z analýzy byly vyloučeny taxony s ojedinělými výskyty, prokazatelné redepozice a kontaminace. Semikvantitativním datům byly $\mathrm{v}$ analýze přiřazeny numerické hodnoty: $\mathrm{x}+\mathrm{cf}=1, \mathrm{~F}=2, \mathrm{~A}=3, \mathrm{D}=4$. Použita byla shluková analýza s algoritmem párových skupin a euklidovským měřením vzdálenosti.

\section{Tafocenózy mikrofauny}

Ve studovaném souboru vzorků bylo zjištěno 60 druhů planktonických foraminifer a více než 133 druhů bentonických (výběr významnějších druhů je v tabulkách 1 a 2). Tafocenózy foraminifer lze empiricky - na základě mikroskopického pozorování - rozdělit do tř́i základních skupin:

1) Relativně diversifikovaný plankton i bentos: plankton je zastoupen druhy Turborotalia ampliapertura, Subbotina angiporoides, S. gortanii, S. yeguaensis, v bentosu jsou typické druhy Hoeglundina elegans, Ceratocancris eximius, Stichocibicides moravicus, Uvigerina spp. aj. Foraminifery doprovází fauna drobných měkkýšů.

2) Středně diversifikovaný plankton i bentos: plankton reprezentují Globigerina praebulloides, G. officinalis, Globoturborotalita ouachitaensis, G. gnaucki, Tenuitella brevispira, Turborotalia ampliapertura, z bentosu jsou typické druhy Bolivina crenulata (často hojně), Escornebovina spp., Virgulopsis tuberculatus, Globocassidulina subglobosa, Caucasina schischkinskayae, Valvulineria sp., Angulogerina spp., Biapertorbis spp. Charakteristický je hojný výskyt kostí, šupin a zubů ryb.
3) Vysoce diversifikovaný plankton i bentos: plankton s Catapsydrax unicavus, Subbotina angiporoides, S. eocaena, S. corpulenta, Globigerinatheka spp., Morozovella spp., Acarinina spp., v bentické složce je typický výskyt Vulvulina haeringensis, Plectina dalmatina, Recurvoides sp., Rhabdammina sp., Cribroparella pteromphalia, Linaresia sp.1, Uvigerina spp. Často se vyskytují hojné radiolarie zachované ve formě neurčitelných křemitých jader.

Tyto tři skupiny lze na základě současných znalostí přiřadit konkrétním litostratigrafickým jednotkám: skupina 1 - pouzdřanské souvrství, 2 - šitbořické vrstvy menilitového souvrství, 3 - němčické souvrství. Některé ze studovaných vzorků obsahovaly tafocenózy s kombinací znaků tří výše zmíněných tafocenóz. Do jisté míry lze uvažovat o redepozici mikrofauny během sedimentace, v mnoha př́padech jsou však tafocenózy postiženy prokazatelnou kontaminací (viz obsáhlejší komentář v Diskusi).

Složení bentosu tafocenózy 1 (pouzdřanské souvrství) ukazuje na normání marinní prostředí na rozhraní sublitorálu a batyálu. Tafocenóza 2 (šitbořické vrstvy) je batymetricky obdobná, ale hojný až masový výskyt $B o$ livina crenulata ukazuje na snížený obsah kyslíku u dna. Tafocenóza 3 (němčické souvrství) častým výskytem aglutinovaných druhů ukazuje na horní až střední batyál a radiolarie poukazují na dobrou komunikaci s oceánem.

\section{Biostratigrafie planktonických foraminifer}

Společenstva planktonu v tafocenózách typu pouzdřanského souvrství lze biostratigraficky zařadit na pomezí eocénu a oligocénu v rozmezí biozón E15 (vyšší polovina) až O1. V těchto společenstvech se vyskytují druhy Globorotaloides suterii, G. variabilis a Tenuitella brevispira považované za oligocenní spolu se Subbotina yeguaensis, jejíž výskyt se udává do konce zóny NP16. Není jednoduché posoudit, zda jde o skutečný spoluvýskyt, nebo redepozici. Prokazatelně redeponované druhy (resp. kontaminace) ze spodního až středního eocénu se v těchto společenstvech vyskytují běžně.

V tafocenózách typu němčického souvrství lze rozlišit několik stratigrafických úrovní:

1) nejvyšší spodní až nižší stř̌ední eocén, interval zón E7-E9 (Ša-15/20-22 m);

2) vyšší střední eocén, interval zón E10-E13 (Ša15/17-19 m);

3) nejvyšší střední až nejnižší svrchní eocén, interval od poloviny E13 po E14 (Ša-13/24-27 m);

4) nejvyšší svrchní eocén, zóna E16 (Ša-13/40-43 m).

Stejně jako $\mathrm{v}$ případě tafocenózy pouzdřanského typu jsou časté starší redepozice/kontaminace nejčastěji ze spodního eocénu, méně z paleocénu.

Tafocenóza typu šitbořických vrstev je provázena planktonem, kterýlze zařadit v rámci spodního oligocénu, interval zón O1-O2. Báze tohoto intervalu je daná známým oligocenním stářím šitbořických vrstev a její horní hranice posledním výskytem Turborotalia ampliapertura, která bývá $\mathrm{v}$ tafocenóze přítomna. 
Tab. 1: Distribuce planktonických foraminifer ve studovaných vzorcích. Značky: x - vzácný, F - častý, A - hojný, D - dominantní, cf - nejistá determinace, $\mathrm{R}$ - přeplavený, $\mathrm{K}$ - kontaminace.

Tab. 1: Distribution of planktonic foraminifers in studied samples. Symbols: $\mathrm{x}$ - rare, F - frequent, A - abundant, D - dominant, $\mathrm{cf}$ - uncertain determination, $\mathrm{R}$ - reworked, $\mathrm{K}$ - contamination.

\begin{tabular}{|c|c|c|c|c|c|c|c|c|c|c|c|c|c|c|c|c|c|c|c|c|c|c|c|c|c|c|c|c|c|c|c|c|c|c|}
\hline & 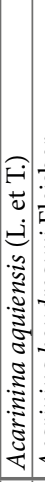 & 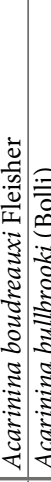 & 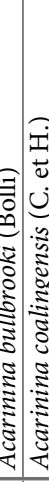 & 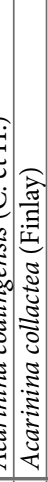 & 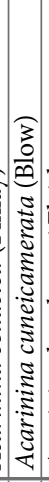 & 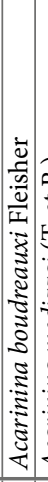 & 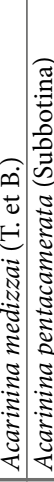 & 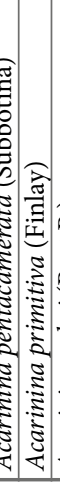 & 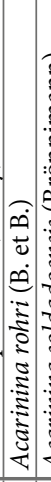 & 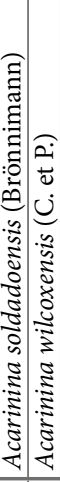 & 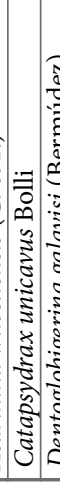 & 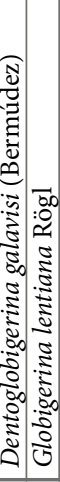 & 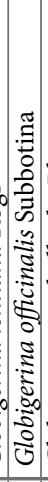 & 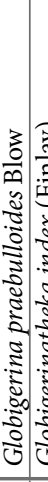 & 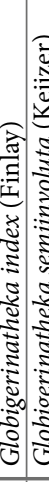 & 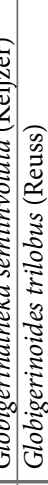 & 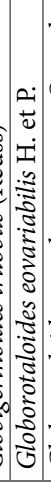 & 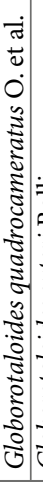 & 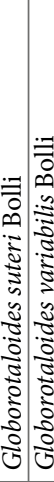 & 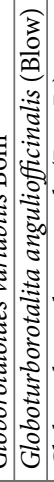 & 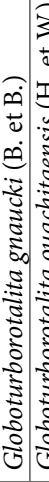 & 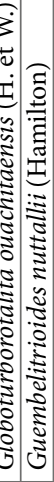 & 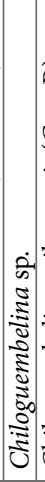 & 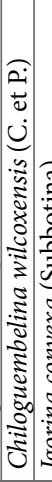 & 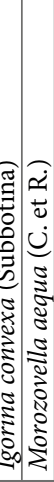 & 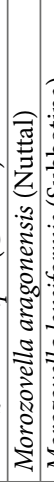 & 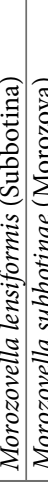 & 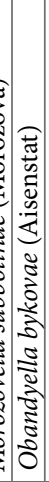 & 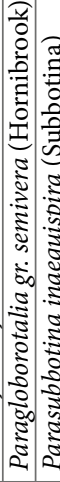 & 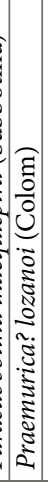 & 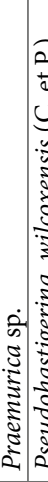 & 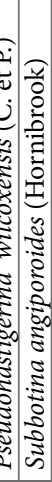 & 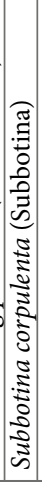 & 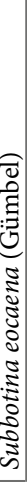 \\
\hline Ša10/22-26 & & & & & & & $\mathrm{x}$ & & & & \begin{tabular}{l|l}
$x$ & $x$ \\
\end{tabular} & $\mathrm{x}$ & & & $\mathrm{x}$ & $\mathrm{x}$ & & & A & & & $\mathrm{x}$ & & & & & & & & & & F & & \\
\hline Ša12/13-17 & & & & & & & & & & & & & $\mathrm{x}$ & $\mathrm{A}$ & & & & & & & \begin{tabular}{l|l}
$\mathrm{x}$ & $\mathrm{A}$ \\
\end{tabular} & A & & & & & & & & & & & & \\
\hline Ša12/18-22 & & & & & & & & & & & & & $\mathrm{x}$ & $\mathrm{F}$ & & & & & & & \begin{tabular}{l|l}
$\mathrm{x}$ & $\mathrm{A}$
\end{tabular} & A & & & & & & & & & & & & \\
\hline Ša12/23-27 & & & & & & & & & & & & & & A & & & & & & & \begin{tabular}{l|l}
$\mathrm{A}$ & $\mathrm{A}$ \\
\end{tabular} & A & & & & & & & & & & & & \\
\hline Ša12/28-32 & & & & & & & & & & & $\mathrm{x}$ & $\mathrm{A}$ & $\mathrm{F}$ & A & & & & & & & \begin{tabular}{l|l}
$x$ & $F$ \\
\end{tabular} & $\mathrm{~F}$ & $\mathrm{x}$ & & & & & & & & & & & \\
\hline Ša12/33-37 & & & & & & & & & & & & $\mathrm{x}$ & $\mathrm{cf}$ & $\mathrm{x}$ & & & & & & & $\mathrm{x}$ & & & & & & & & & & & & & \\
\hline Ša12/38-42 & & & & & & & & & & & & & $\mathrm{x}$ & $\mathrm{x}$ & & & & & & & \begin{tabular}{l|l}
$\mathrm{x}$ & $\mathrm{x}$ \\
\end{tabular} & $\mathrm{x}$ & & & & & & & & & & & & \\
\hline Ša12/43-47 & & & & & & & & & & & & & & & & & & & & & \begin{tabular}{l|l}
$\mathrm{A}$ & $\mathrm{x}$ \\
\end{tabular} & $\mathrm{x}$ & & & & & & & & & & & & \\
\hline Ša12/48-52 & & & & & & & & & & & & & & \begin{tabular}{l|l}
$x$ & $x$ \\
\end{tabular} & $\mathrm{x}$ & & & & $\mathrm{x}$ & $\mathrm{cf}$ & $\mathrm{x}$ & & & & & & & & & & & & $\mathrm{x}$ & $\mathrm{x}$ \\
\hline Ša12/58-61 & & & \begin{tabular}{l|l}
$\mathrm{R}$ & $\mathrm{R}$
\end{tabular} & & $\mathrm{R}$ & & \begin{tabular}{l|l}
$\mathrm{R}$ & $\mathrm{R}$ \\
\end{tabular} & $\mathrm{R}$ & & $\mathrm{R}$ & & & & $\mathrm{x}$ & & & & & & & & & & & $\mathrm{x}$ & & & $\mathrm{K}$ & & $\mathrm{R}$ & & $\mathrm{R}$ & $\mathrm{x}$ & \\
\hline Ša13/16-19 & & & & & & & & & & & & & & A & & & & & & & & $\mathrm{x}$ & & & & & & & & & & & $\mathrm{F}$ & \\
\hline Ša13/20-23 & & & & & & & & & & & $\mathrm{x}$ & & $\mathrm{x}$ & A & & & $\mathrm{cf}$ & & & & \begin{tabular}{l|l}
$\mathrm{x}$ & $\mathrm{F}$ \\
\end{tabular} & $\mathrm{F}$ & & & & & & & & & & & $\mathrm{x}$ & \\
\hline Ša13/24-27 & & & & & & & & & & & & & & & $\mathrm{x}$ & $\mathrm{x}$ & & & & & & & & & $\mathrm{R}$ & & \begin{tabular}{l|l}
$\mathrm{R}$ & $\mathrm{R}$ \\
$\mathrm{y}$
\end{tabular} & & & & & & $\mathrm{x}$ & A \\
\hline Ša13/28-31 & & & & & & & & & & & $\mathrm{x}$ & & & & $\mathrm{x}$ & & & & $\mathrm{x}$ & & & $\mathrm{x}$ & & & & & & & & & & $\mathrm{F}$ & $\mathrm{F}$ & \\
\hline Ša13/32-35 & & $\mathrm{x}$ & & & & $\mathrm{R}$ & & & & & $\mathrm{F}$ & & & & & & $\mathrm{F}$ & & & & & $\mathrm{x}$ & & & & & & & & & $\mathrm{R}$ & $\mathrm{F}$ & $\mathrm{x}$ & \\
\hline Ša13/36-39 & & & & & & & & & & & A & & & & & & & & & & & & & & & & & & & & & & & \\
\hline Ša13/40-43 & & & & $\mathrm{R}$ & & & & & & & $\mathrm{x}$ & & & A & & & & & & $\mathrm{F}$ & & $\mathrm{x}$ & & & & & & & & & & & & \\
\hline Ša13/44-47 & & & & & & & & & & & & & $\mathrm{x}$ & $\mathrm{x}$ & & & & & & & $\mathrm{x}$ & & & & & & & & & & & & & \\
\hline Ša13/48-51 & & & & & & & & & & & & & & $\mathrm{D}$ & & & & & & & & & & & & & & & & & & & & \\
\hline Ša13/52-55 & & & & & & & & & & & & & & $\mathrm{cf}$ & & & & & & & & & & & & & & & & & & & & \\
\hline Ša13/56-59 & & & & & & & & & & & & $\mathrm{x}$ & & $\mathrm{x}$ & & & & & & & $\mathrm{cf}$ & & & & & & & & $\mathrm{x}$ & & & & & \\
\hline Ša13/64-68 & & & & & & & & & & & & & & $\mathrm{x}$ & & & & & & & & & & & & & & & & & & & & \\
\hline Ša15/11-16 & & $\mathrm{x}$ & & & & $\mathrm{R}$ & & & & & $\mathrm{x}$ & & & $\mathrm{x}$ & & & & & & & & & & & & & & & & & & \begin{tabular}{l|l}
$R$ & $x$ \\
\end{tabular} & $\mathrm{x}$ & $\mathrm{x}$ \\
\hline Ša15/17-19 & $\mathrm{R}$ & & $\mathrm{R}$ & & $\mathrm{R}$ & & & & \begin{tabular}{l|l}
$\mathrm{R}$ & $\mathrm{I}$
\end{tabular} & $\begin{array}{ll}\mathrm{R} & \mathrm{R} \\
\end{array}$ & $x$ & & & & & K & र & & & & $\mathrm{x}$ & & & & & & & & & & & & & $\mathrm{x}$ \\
\hline Ša15/20-22 & & & $\mathrm{x}$ & & $\mathrm{x}$ & & & $\mathrm{x}$ & & & & & & & & K & K & & & & & $\mathrm{x}$ & & & & $\mathrm{x}$ & & & & & & $\mathrm{x}$ & & $\mathrm{x}$ \\
\hline Ša15/35-37 & & & & & & & & & & & $\mathrm{x}$ & & & & & & & $\mathrm{cf} 1$ & $\mathrm{~K}$ & & & & & & & & & & & & & & & \\
\hline Ša15/38-40 & & & & & & & & & & & $\mathrm{x}$ & & & & & & & & & & & & & & & & & & & & & $\mathrm{x}$ & & \\
\hline Ša15/41-43 & & & & & & & & & & & $\mathrm{x}$ & & & & & & & & $\mathrm{cf}$ & & & & & & & & & & & & & & & \\
\hline Ša15/44-46 & & & & & & & & & & & & & & & & & & & $\mathrm{cf}$ & & & & & & & & & & & & & & & \\
\hline Ša15/47-49 & & & & & & & & & & & $\mathrm{x}$ & & & & & & & $\mathrm{x}$ & & & & & & & & & & & & & & & $\mathrm{x}$ & \\
\hline Ša15/50 & & & & & & & & & & & $\mathrm{cf}$ & & & & & & & & & & & & & & & & & & $\mathrm{x}$ & & & & & \\
\hline
\end{tabular}

\section{Diskuze}

Jak je výše uvedeno, zařazení vzorků k litostratigrafickým jednotkám bylo provedeno na základě mikropaleontologického datování, charakteru tafocenóz a litologie. Pro potvrzení objektivity interpretace byla použita shluková analýza (viz metodika). U planktonických foraminifer nevedla analýza $\mathrm{k}$ použitelnému výsledku. Společenstvo planktonu je podobné u vzorků stejného stáří, tudíž nemůže rozlišit sedimenty pouzdřanského souvrství od němčického $\mathrm{v}$ případě stejného stárí (svrchní eocén). Navíc výsledek analýzy znehodnotily četné redepozice a kontaminace, které nelze spolehlivě odfiltrovat. Principielně je pro zařazení sedimentů k souvrstvím vhodnější bentos, který je závislý na faciálních odlišnostech (viz Tafocenózy mikrofauny). Výsledek shlukové analýzy skutečně potvrdil ve většině prrípadů empirické zařazení podle bentosu, a to v 29 prípadech z 35 (obr. 2). Na místě je rozbor př́ícin jiného zařazení u 6 vzorků:

Ša-13/16-19 m. Chudé společenstvo planktonu (4 druhy) je doprovázeno chudým bentosem (10 taxonů). Plankton dovoluje zařazení v rozsahu střední eocén až oligocén. Bentos obsahuje některé prvky tafocenózy šitbořického i pouzdřanského typu. Podle popisu jádra šlo o tmavě šedý a šedohnědý písčitý jíl se „skořápkami zkamenělin“ (ve výplavu zjištěny zbytky ostnokožců a mechovek). Podle litologie a vápnité makrofauny lze vzorek 


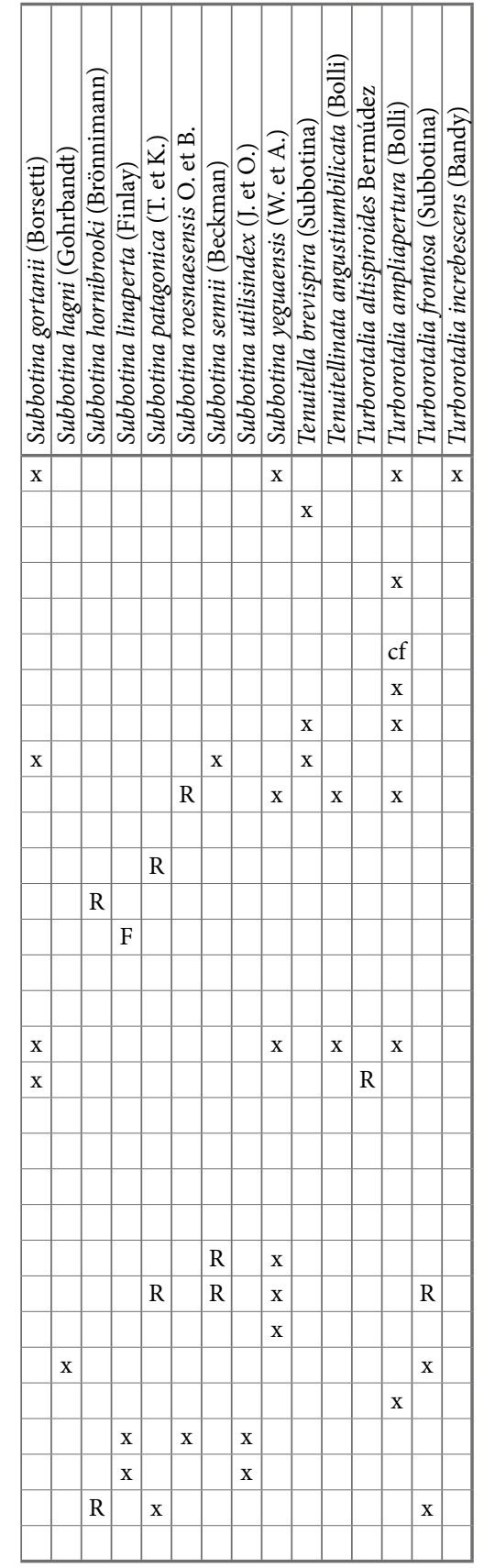

zařadit do pouzdřanského souvrství, tafocenóza je každopádně atypická a může být směsí fauny pouzdřanského a menilitového souvrství.

Ša-13/28-31 m. Nepř́iliš rozmanité společenstvo planktonu středního eocénu je doprovázeno bentosem typu pouzdřanského souvrství. Podle popisu šlo o tmavě zelenošedé a světle šedozelené vápnité jíly s pískovci a uhlím(?). Výskyt měkkýšů (Spiratella sp. a Nucula sp.) a hnědá jílovitá výplň schránek ukazují původ z pouzdřanských slínů. Mikrofauna je pseudoasociací pouzdřanského a němčického souvrství, přičemž litologie odpovídá němčickému. Ša-13/52-55 m. Velmi chudá mikrofauna poškozená rozkladem pyritu obsahuje prvky tafocenózy šitbořického

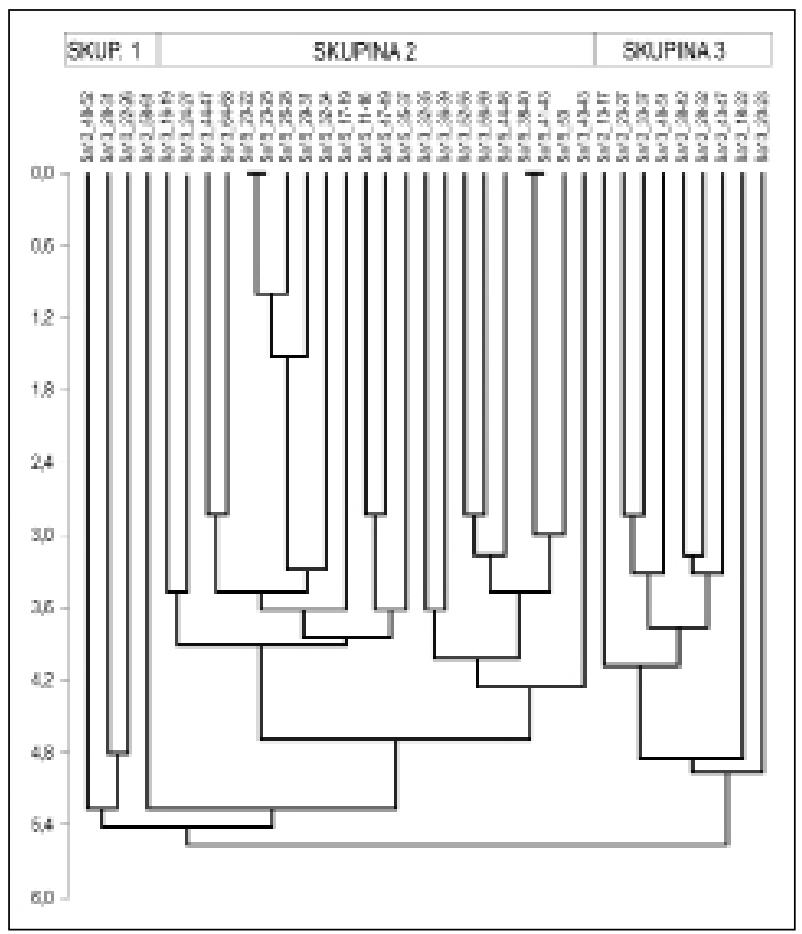

Obr. 2: Výsledek shlukové analýzy společenstev bentosních foraminifer.

Fig. 2: Result of the cluster analysis of the benthic foraminifer communities.

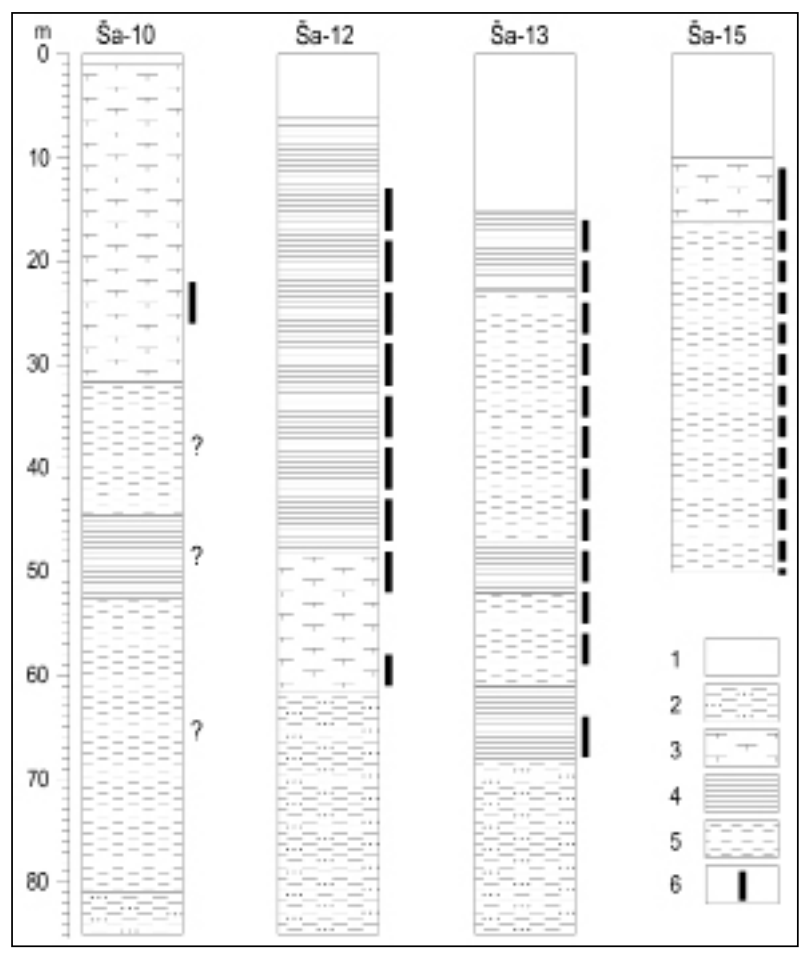

Obr. 3: Interpretace profilu vrtů na základě mikropaleontologie a litologie s vyznačením studovaných vzorků. 1 - kvartérní pokryv, 2 - laaské souvrství (jíly), 3 - pouzdřanské souvrství (slíny, jíly), 4 - šitbořické vrstvy menilitového souvrství (jíly), 5 - němčické vrstvy (jíly), 6 - vzorek.

Fig. 3: Interpretation of the borehole sections based on micropalaeontology and lithology with indicated position of samples. 1 - Quaternary cover, 2 - Laa Formation (clays), 3 - Pouzdřany Formation (marls, clays), 4 - Šitbořice Beds of the Menilite Formation (clays), 5 - Němčice Formation (clays), 6 - sample. 
Tab. 2: Distribuce bentických foraminifer a ostatní mikrofauny ve studovaných vzorcích. Značky viz tab. 1; o - taxony použité ve shlukové analýze.

Tab. 2: Distribution of benthic foraminifers and other microfossils in studied samples. For symbols see Tab. 1.; $\mathrm{o}$ - taxa used in cluster analysis.

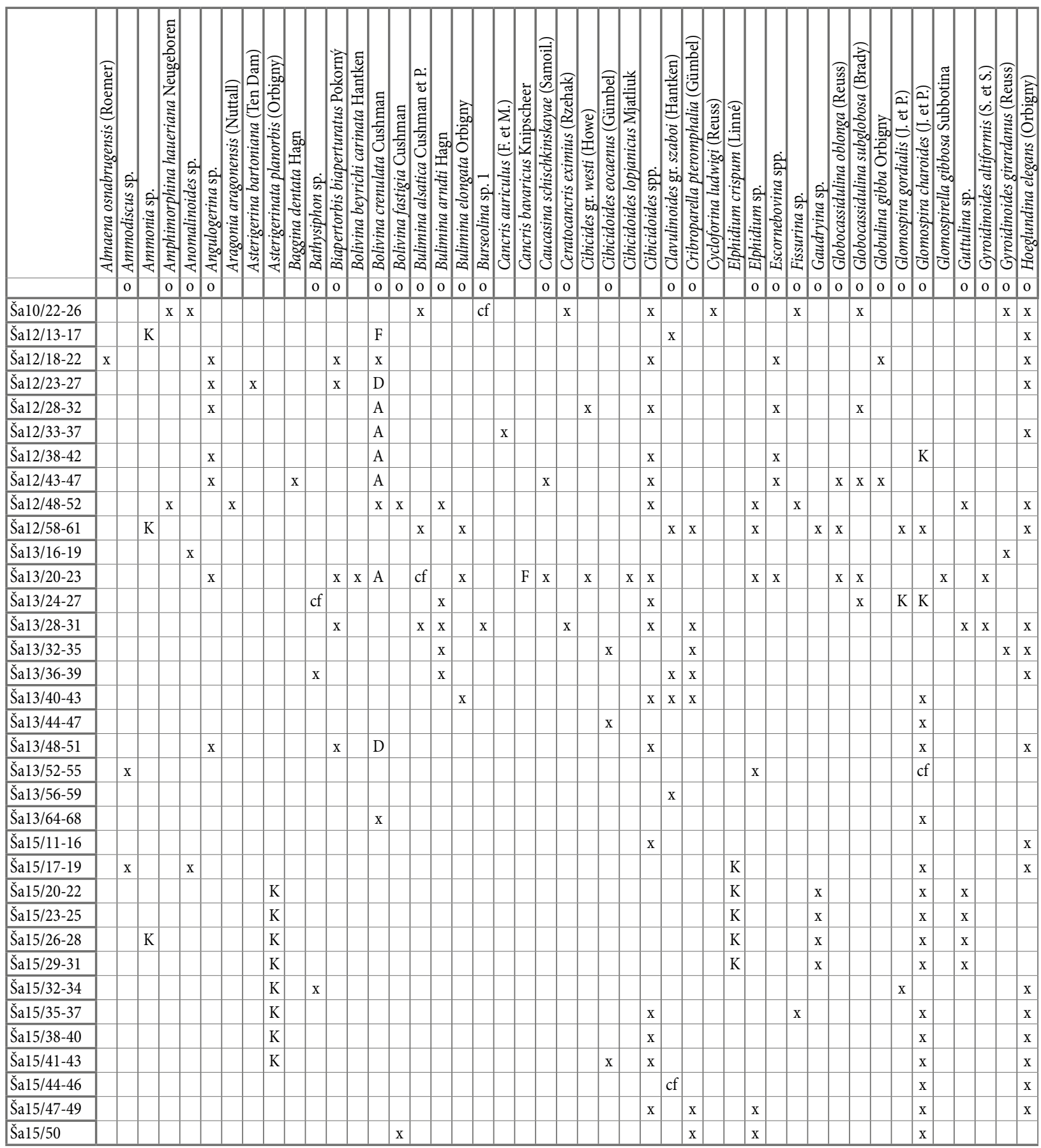

typu a zároveň hojná jádra radiolarií charakteristická pro němčické souvrství (pseudoasociace). Litologie - tmavě hnědošedý vápnitý jílovec a hnědošedý jíl - odpovídá spíše šitbořickým vrstvám.

Ša-13/56-59 m. Litologie popsána jako hnědošedý jíl, mikrofauna obdobná jako předchozí vzorek. Patrně jde o šitbořické vrstvy.

Ša-13/64-68 m. Velmi chudá mikrofauna obdobná jako u předchozích dvou vzorků, ale bez radiolarií. Litologie - tmavošedý a tmavě hnědošedý jíl - ukazuje opět na šitbořické vrstvy.
Ša-15/11-16 m. Eocenní subbotinový plankton je doprovázen bentosem s prvky pouzdřanského souvrství a drtí měkkýšů. Litologicky šlo o tmavě šedé a černošedé vápnité jíly, což upomíná rovněž na pouzdřanské souvrství. $\mathrm{Na}$ přiřazení do skupiny vzorků němčického souvrství shlukovou analýzou má pravděpodobně podíl kontaminace během vrtání.

Jako problematický se jeví rovněž vzorek Ša12/58-61 z pomezí skupiny 1 a 2 (obr. 2). Pseudoasociace mikrofauny obsahuje typické prvky bentosu pouzdřanského souvrství, ale plankton ukazuje na značnou příměs redepozic (?) 


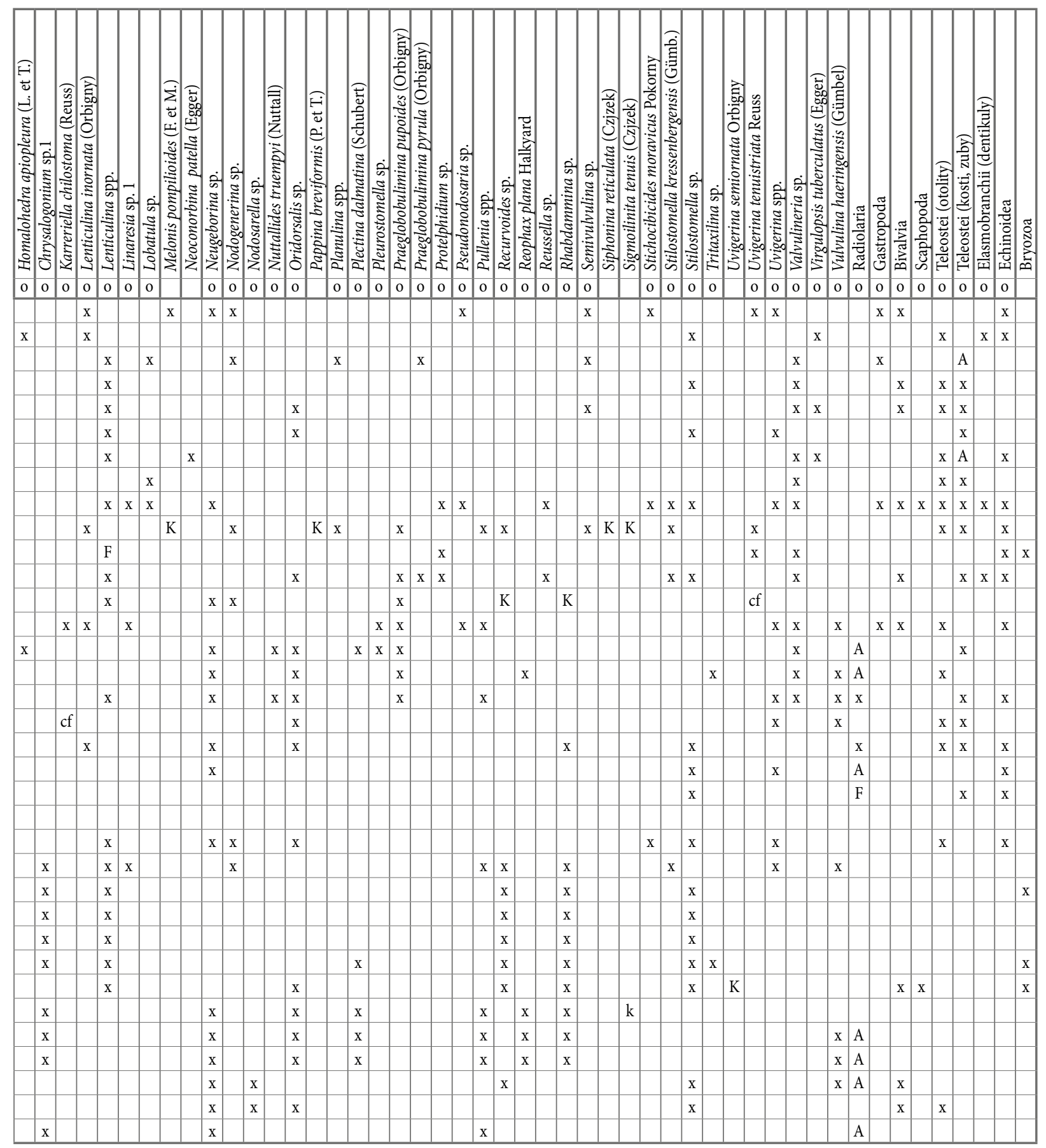

i kontaminaci (badenské a karpatské druhy). Litologicky je daný interval popsán jako světle šedozelené a tmavě zelenošedé jíly, což ukazuje spíše na němčické než pouzdřanské souvrství.

Pochopení problematiky redepozic a kontaminací má zásadní význam pro správnou geologickou a biostratigrafickou interpretaci vzorků. Prokazatelná kontaminace byla zjištěna ve vzorcích z vrtu Ša-15. Prakticky v celém profilu vrtu vzorky obsahovaly vedle paleogenních druhů i časté miocenní taxony charakteristické pro baden. Badenská mikrofauna byla zjištěna i v četných povrchových vzorcích (vyorávky jílů z polí, ruční vrty) odebraných během geologického mapování $\mathrm{z}$ okraje flyšových Karpat. Tato mikrofauna nepochází z předhlubně, protože na jejím v. okraji se vyskytuje laaské souvrství karpatu. Jejím zdrojem budou pravděpodobně relikty badenských sedimentů pokrývající vrcholy kopců v. od Šaratic. Jde patrně o štěrky s vložkami písků a jílů, jaké byly zjištěny i u Újezdu u Brna (Bubík et al. 1999). Vedle charakteristických badenských foraminifer Obandyella bykovae, Elphidium crispum, Amphistegina sp., Asterigerinata planorbis, Ammonia viennensis, Ceratocancris haueri, Sigmoilinita 
tenuis, Uvigerina semiornata a úlomků mechovek obsahují i redepozici z karpatu (Pappina breviformis) a prakticky všech paleogenních souvrství pouzdřanské a ždánické jednotky. Ve vrtu Ša-15 pocházejí kontaminace velmi pravděpodobně ze žlutošedého drobnozrnného křemenného štěrku (1-5 m) a šedého vápnitého písčitého jílu (5-10 m) uvedených $\mathrm{v}$ původním popisu vrtu.

$\mathrm{V}$ úvahu je nutno vzít rovněž to, že vzorky reprezentují 2 až $4 \mathrm{~m}$ dlouhý interval vrtného jádra, což mohlo být vynuceno malým ziskem jádra a zároveň jeho malým průměrem používaným při „counterflush“ vrtání. Sedimenty s vysokou převahou jílovců a jílů na okraji (bázi) příkrovů flyšového pásma jsou nepochybně tektonicky postiženy. Pokud se ve vzorkovaném intervalu střídaly tenké tektonické šupiny např. němčického a pouzdřanského souvrství, výsledkem by byly právě takovéto pseudoasociace jako ty diskutované výše. $V$ takovémto př́padě ani není nutno uvažovat o redepozicích ze starších úrovní paleogénu, nebot i toto mohou být kontaminace způsobené smícháním různě starých hornin při vzorkování. Současné mikropaleontologické metodiky by mohly objasnit tyto spekulace i na základě velmi malých kousků jádra. To však nebylo k dispozici.

V prrípadě vrtu Š-10 byl k dispozici jediný vzorek na foraminifery. Velká část profilu je interpretována pouze na základě litologie a tato interpretace nemusí být správná (obr. 3).

Zatím zůstává nevyřešené, proč nebyly v okrajové zóně zjištěny podrohovcové vrstvy, rohovcové vrstvy ani dynowské slínovce menilitového souvrství. Nabízí se spekulace, že v okrajové zóně ždánické jednotky mají tyto členy menilitového souvrství odlišnou litologii. Menilitové rohovce a dynówské slínovce jsou prakticky nezaměnitelné horninové typy, navíc odolné k zvětrávání. Jediným známým výskytem rohovce v okolí Šaratic je hnědošedý rohovec mocný $10 \mathrm{~cm} \mathrm{z}$ vrtu Ša-15 $(47,8-47,9 \mathrm{~m})$ podle původního popisu Cílka (1957). Rohovec není označen jako menilitový a poloha se nachází v rámci němčického souvrství. Jádro není k dispozici. Zda se menilitové souvrství okrajové zóny ždánické jednotky skutečně litologicky liší, bude možné rozhodnout, až budou nalezeny stratigrafické ekvivalenty jeho členů.

Pro existenci faciálně odlišné okrajové zóny existují určité indicie zjištěné během podrobného mapování (Tomanová Petrová et al. 2013). Jíly šitbořických vrstev $s$ charakteristickou mikrofaunou se makroskopicky nedaly odlišit od jílů hustopečského typu. Ždánicko-hustopečské souvrství je v této oblasti prakticky bez pískovců. Jíly hustopečského typu s egerskou foraminiferovou faunou obsahují hojné sklovitě průhledné jehlice hub a rozsivky. Ve vnitřnějších zónách ždánické jednotky křemité mikrofosilie prakticky chybí a zejména křehké rozsivky podlehly diagenezi vzhledem k nestabilitě opálu. To naznačuje, že sedimenty okrajové zóny ždánické jednotky se ukládaly $\mathrm{v}$ mělčím prostředí.

\section{Závěr}

Mikropaleontologická revize archivního mikropaleontologického materiálu z šaratických Cf vrtů dovolila zpřesnění jejich profilu a přinesla nové poznatky o strukturní stavbě a stratigrafii okraje flyšového pásma jv. od Brna. Oproti původnímu zařazení celé okrajové zóny flyšového pásma k němčickému souvrství (Cílek 1957) byly nově rozlišeny jednotky pouzdřanská (pouzdřanské souvrství) a ždánická (němčické a menilitové souvrství). Okrajová zóna je tvořena tektonickými šupinami, jejichž pořadí a počet se mění od vrtu k vrtu (obr. 3).

\section{Poděkování}

Autor děkuje Pavlu Hudcovi za zpřístupnění fosilního materiálu $z$ depozitáře MND pro účel revize. Revize mikrofauny byla provedena $v$ rámci projektu ČGS 390003 (Základní geologické mapování Brnènské aglomerace v měřitku 1:25000).

\section{Literatura}

Brzobohatý, R. - Čekan, V. - Čtyroký, P. - Dvořák, J. - Eliáš, M. - Friáková, O. - Ivan, A. - Líbalová, J. -Machatková, B. - Otava, J. - Řeháková, Z. - Stráník, Z. (1987): Základní geologická mapa 1: 25000 s textovými vysvětlivkami, list 22-431 Šlapanice. - MS Česká geologická služba, Praha, 74 str., 10 př́l.

Cílek, V. (1957): Zpráva o strukturním průzkumu v oblasti vněkarpatské pánve jižně od Nosislavi a u Šaratic. - MS Československé naftové doly Brno, 25 str., 5 př́il.

Olsson, R. K. - Hemleben, Ch. - Berggren, W. A. - Huber, B. T. (1999): Atlas of Paleocene Planktonic Foraminifera. - Smithsonian Contributions to Paleobiology, 85, 252 pp., Washington.

Pearson, P. N. - Olsson, R. K. - Huber, B. T. - Hemleben, C. - Berggren, W. A. (2006): Atlas of Eocene Planktonic Foraminifera. - Cushman Foundation Special Publication No. 41, 514 pp., Fredericksburg.

Bubík, M. - Novák, Z. - Stráník, Z. (1999): Předběžné výsledky geologické dokumentace rýhy plynovodu Újezd u Brna-Otnice. - Geol. výzk. Mor. Slez. v roce 1998, 47-51.

Hammer, Ø. - Harper, D. A. T. - Ryan, P. D. (2001): PAST: Paleontological Statistics Software Package for Education and Data Analysis. - Palaeontologia Electronica, 4, 1, 1-9.

Tomanová Petrová, P. - Baldík, V. - Bubík, M. - Buriánek, D. - Franců, J. - Fürychová, P. - Gilíková, H. - Havlín, A. - Janderková, J. - Kociánová, L. - Kolejka, V. - Konečný, F. - Krejčí, O. - Krejčí, V. - Kryštofová, E. - Kunceová, E. - Otava, J. - Paleček, M. - Pecina, V. - Pecka, T. - Rez, J. - Sedláček, J. Mgr. - Sedláčková, I. - Skácelová, Z. - Švábenická, L. - Večeřa, J. - Vít, J. (2013): Vysvětlivky k základním geologickým mapám České republiky 1 : 25000 24-431 Šlapanice. - MS Archiv České geologické služby, 216 str. 